\title{
PENGEMBANGAN KREATIVITAS DAN KONSEP DIRI ANAK SD
}

\author{
${ }^{1}$ Kurnia Puspita Sari, ${ }^{2}$ Neviyarni, ${ }^{3}$ Irdamurni \\ ${ }^{1}$ kurniapuspitasari248@gmail.com, ${ }^{2}$ neviyarni.suhaili911@gmail.com, \\ 3irdamurni241161@gmail.com
}

Prodi Pendidikan Dasar Program Pascasarjana, Universitas Negeri Padang

\begin{abstract}
ABSTRAK
Permasalahan yang terlihat di sekolah dasar yaitu pembelajaran belum mengoptimalkan proses kreativitas pada diri siswa serta kebanyakan siswa tidak dapat mengenal potensinya. Kecenderungan mereka di sekolah, belum mampu berpikir secara logis terhadap peristiwa yang sifatnya nyata, pengembangan konsep diri pada mereka belumlah optimal sehingga siswa cenderung belum mampu berargumentasi dalam memecahkan masalah. Padahal seharusnya proses berpikir kreatif siswa perlu diberikan sejak usia SD. Tujuan pembahasan ini adalah untuk mengetahui pengembangan kreativitas serta konsep diri anak SD. Metode kepustakaan (library research) digunakan sebagai metodologi penelitian dalam penelitian ini. Teknik pengumpulan data dalam pembahasan ini dengan mengkaji atau mengeksplorasi beberapa buku, jurnal serta dokumen lain yang dianggap relevan. Penelitian ini membahas tentang hal yang penting dalam pendidikan yaitu kreativitas dengan demikian mengoptimalkan kreativitas sepatutnya dilakukan sejak SD. Pengetahuan dalam mengekspresikan serta mengaktualisasikan diri dalam bentuk yang terstruktur baik kaitannya dengan diri sendiri, alam maupun orang lain hal itu adalah pengertian dari kreativitas. Kreativitas erat kaitannya dengan konsep diri. Konsep diri yaitu pengevaluasian tentang kepantasan diri pribadi diungkapkan dalam bentuk sikap tentang dirinya. Guru seharusnya memahami apa saja hal-hal yang dapat meningkatkan konsep diri serta kreativitas bagi diri anak agar perkembangannya dapat berjalan optimal, tentunya hal tersebut tidak luput dari pengaruh lingkungan keluarga, sekolah dan masyarakat.
\end{abstract}

Kata kunci: kreativitas, konsep diri, anak SD

\section{DEVELOPMENT OF CREATIVITY AND SELF-CONCEPT OF CHILDREN PRIMARY SCHOOL}

\author{
${ }^{1}$ Kurnia Puspita Sari, ${ }^{2}$ Neviyarni, ${ }^{3}$ Irdamurni \\ ${ }^{1}$ kurniapuspitasari248@gmail.com, ${ }^{2}$ neviyarni.suhaili911@gmail.com, \\ 3irdamurni241161@gmail.com
}

Prodi Pendidikan Dasar Program Pascasarjana, Universitas Negeri Padang

\begin{abstract}
The problem seen in elementary schools is that learning has not yet optimized the process of creativity in students and most students cannot recognize their potential. Their tendency in school, has not been able to think logically about events that are real, the development of selfconcept in them is not optimal so students tend not to be able to argue in solving problems. Even though the student's creative thinking process should be given from elementary school age. The purpose of this discussion is to find out the development of creativity and self-concept of elementary school children. The library research method is used as a research methodology in this study. Data collection techniques in this discussion by reviewing or exploring several books,
\end{abstract}

44 | Jurnal Ilmiah “Pendidikan Dasar” Vol. VII No. 1 Januari 2020 
journals and other documents that are considered relevant. This research discusses the important thing in education, namely creativity, thus optimizing creativity should be done since elementary school. Knowledge in expressing and actualizing oneself in a structured form both in relation to oneself, nature and others is an understanding of creativity. Creativity is closely related to selfconcept. The concept of self, namely the evaluation of personal self-efficacy expressed in the form of attitudes about him. Teachers should understand what are the things that can improve selfconcept and creativity for children so that their development can run optimally, of course it is not immune to the influence of the family, school and community environment.

Keywords: creativity, self-concept, elementary school children

\section{PENDAHULUAN}

Kreativitas merupakan suatu tuntutan pendidikan dan kehidupan yang penting pada saat ini. Individu dan organisasi yang kreatif akan selalu dibutuhkan oleh lingkungan karena mereka mampu memenuhi kebutuhan lingkungan yang terus berubah. Potensi kreatif pada dasarnya dimiliki oleh setiap siswa, karena mereka memiliki ciri sebagai individu kreatif misalnya: rasa ingin tahu yang besar, senang bertanya, imajinasi yang tinggi, berani menghadapi resiko dan lain sebagainya. Ada beberapa faktor yang mempengaruhi hal tersebut diantaranya guru, orang tua dan lingkungan.

$$
\text { Menurut Bayanie }
$$

kreativitas yaitu potensi yang penting bagi diri anak. Melalui kreativitas, ia mampu memecahkan masalah yang dihadapinya secara efektif dan efisien nantinya mereka memiliki kemungkinan untuk sukses dimasa yang akan datang.
Seorang anak sebaiknya sejak dini digali kreativitasnya. Kreativitas dimaksudkan kompetensi dalam mengkombinasikan suatu hal menjadi sesuatu yang baru didasarkan pada komponen yang telah ada hingga membentuk suatu hal yang berguna.

Gagasan kreatif yang muncul berguna bagi semua orang terbukti dengan pesatnya kemajuan teknologi dan informasi mempermudah aktivitas manusia. Semua itu merupakan salah satu hasil dari sebuah kreativitas.

Untuk mewujudkan pribadi yang kreatif tidak luput dari faktor perkembangan konsep diri anak tersebut. Faktor penentu dalam keberhasilan perkembangan setiap anak dilihat dari aspek konsep diri. Sifat khas pada diri individu yang membedakan antara satu dengan yang lainnya disebut konsep diri.

$\begin{array}{lll}\text { Konsep } & \text { diri } & \text { seseorang dapat } \\ \text { dilihat dari } & \text { sikap dirinya berupa } \\ \text { menifestasi dari orang tersebut. }\end{array}$


Manusia sejatinya diberikan rangsangan untuk berkembang sehingga membuat dirinya sadar akan keberadaannya. Seluruh proses yang telah dialaminya pun sejatinya akan membantu ia dalam membentuk kepribadiannya.

Berdasarkan uraian di atas terdapat beberapa permasalahan yaitu pertama, adanya keyakinan di masyarakat bahwa anak yang kreatif itu sifatnya genetik diturunkan dari orangtuanya padahal anggapan seperti itu tidak mutlak. Kedua, anggapan masyarakat bahwa anak yang tekun bekerja adalah mereka yang punya kecerdasan dan berprestasi, cenderung lebih berhasil dalam kehidupan ketimbang mereka yang kreatif. Ketiga, anggapan di masyarakat bahwa sedikit orang yang mempunyai kemampuan berkreasi. Keempat, anggapan ilmuwan bahwa kreativitas sulit dipelajari dan diukur. Permasalahan yang terlihat di sekolah, pada dasarnya kreativitas menekankan adanya dorongan atau lingkungan pendukung/pendorong terwujudnya kreativitas itu, dalam kegiatan pembelajaran hal tersebut belum terwujud, bahkan ada kecenderungan menghambat terhadap pengembangan kreativitas siswa (Suherman, 2010:133). Permasalahan lain yang tampak di sekolah, kekreatifan anak akan terasa hilang karena jarang diekspose keluar dan terasa tidak bernilai. Karena hal tersebut membuat mereka untuk tidak mengasah kekreatifannya. Jika dilihat pada saat sekarang ini pendidikan belum optimal dalam membentuk siswanya menjadi pribadi yang kreatif. Kecenderungan mereka dipersiapkan untuk menjadi tenaga teknis ketimbang menjadi seorang visioner. Baik materi ataupun proses pembelajaran yang dipelajari di sekolah kurang berkontribusi untuk mempersiapkan mereka untuk terjun ke lapangan. Dikarenakan proses pengembangan kreativitas yang belum bisa dioptimalkan, hal tersebut berdampak kepada perkembangan konsep diri.

Permasalahan yang terlihat siswa kurang percaya dengan potensi yang dimilikinya. Padahal kesuksesan seseorang dipengaruhi oleh cara ia memandang kompetensi yang dimilikinya. Anggapan negatif terhadap kemampuan dirinya menyebabkan seseorang memandang setiap tugas yang diberikan kepadanya sebagai sesuatu yang sulit untuk diselesaikan, sehingga penting kiranya memahami akan konsep diri itu sendiri.

Anak yang memiliki kreativitas tinggi mereka cenderung berkarya lebih banyak kedepannya. Mereka dapat menciptakan hal-hal baru diluar

45 | Jurnal Ilmiah "Pendidikan Dasar" Vol. VII No. 1 Januari 2020 
pemikiran kita. Hal tersebut terwujud dengan adanya perkembangan konsep diri yang optimal. Berdasarkan pemaparan di atas, karena pentingnya pemahaman pengembangan kreativitas dan konsep diri anak SD, maka diperlukan kajian studi kepustakaan untuk membahasnya. Untuk itu perlu dibicarakan pembahasan tentang "Pengembangan Kreativitas dan Konsep Diri Anak SD”.

Tujuan pembahasan ini adalah "Mendeskripsikan pengembangan kreativitas dan konsep diri anak SD".

Pembahasan dalam penelitian ini, berbeda dari penelitian sebelumnya yaitu terfokus untuk mengkaji tentang bagaimana perkembangan kreativitas dan konsep diri anak dimulai sejak usia SD. Hal tersebut dikaji karena pentingnya perkembangan kreativitas dan konsep diri yang optimal bagi anak terutama anak SD agar lahir generasi yang kreatif dengan pribadi yang tangguh.

\section{METODE PENELITIAN}

Pembahasan dalam penelitian ini menggunakan metodologi penelitian kepustakaan (library research). Penelitian berbasis literatur yaitu bentuk penelitian yang menggunakan literatur sebagai objek kajian. Ada beberapa ciri utama yang perlu diperhatikan dalam metode penelitian studi pustaka yaitu: Pertama, penulis dihadapkan langsung dengan teks/data angka. Kedua, bahan pustaka diartikan sebagai sumber kedua artinya penulis memperoleh informasi dari pihak kedua bukan orisinil dari pihak pertama di lapangan. Ketiga, data/informasi yang diperoleh bersifat "siap pakai". Keempat, bahan pustaka yang diperoleh tidak dibatasi ruang dan waktu (Zed, 2003:3). Teknik pengumpulan data yang dilakukan dengan cara mengkaji beberapa buku, literatur serta dokumen lain yang dianggap sesuai dengan kajian di atas.

\section{HASIL DAN PEMBAHASAN}

\section{Pengembangan Kreativitas Anak SD}

Menurut Munandar (2004:21), perwujudan dari proses hubungan manusia terhadap tempat tinggalnya, potensi dirinya dalam membentuk sesuatu yang baru didasarkan fakta, diartikan dengan kreativitas. Kreativitas didefinisikan sebagai perwujudan gagasan atau teori yang inovatif yang sifatnya baru, kreatif juga didefinisikan sebagai suatu usaha produktif yang unik dari seseorang (Budiarti, 2015:66). Berdasarkan hal tersebut kita ketahui bahwa dalam pendidikan, kreativitas amat penting dalam mengembangkan materi yang dipelajari menjadi sesuatu 46 | Jurnal Ilmiah “Pendidikan Dasar” Vol. VII No. 1 Januari 2020 
yang unik dan bermanfaat. Untuk itu pengembangan kreativitas seharusnya dilakukan sejak dini.

\section{Menurut Williams dalam} (Munandar, 2015:24) karakteristik kreativitas, dapat dibagi menjadi dua kategori yaitu: a) ketegori pengetahuan, berkaitan dengan potensi bernalar yang menyebar, b) kategori sikap, berkaitan dengan perilaku serta perasaan seseorang. Pentingnya mengoptimalkan potensi kreatif sejak usia sekolah dasar antara lain: 1) mengembangkan imajinasinya, dengan hal tersebut membuat ia bisa mengoptimalkan potensi dirinya sendiri hal demikian sifatnya penting karena merupakan hal pokok dari suatu individu, 2) diartikan sebagai potensi dirinya dalam mencari metodemetode baru untuk menyelesaikan berbagai persoalan yang ditemuinya, 3) menyibukkan anak dengan suatu hal yang inovatif sangat berguna bahkan membuat ia merasa bahagia. Disimpulkan bahwa dari nilai-nilai kreatif seseorang, akan dapat melahirkan gagasan-gasasan, temuan, ciptaan atau teknologi modern yang nantinya membantu manusia dalam menjalankan aktivitasnya (Munandar, 2015:25).

\section{Pengembangan Konsep Diri}

Konsep diri diartikan sebagai suatu anggapan yang mengarah kepada pribadi seseorang yang membuat ia dapat mengatakan pada dirinya siapa sebenarnya diriya. Selain itu konsep diri pada hakikatnya tidak terlepas dari dirinya sendiri dan upaya ia dalam memahami dunianya (Surna, 2014:56). Menurut Muawanah (2012:8) anggapan seseorang tentang diri sendiri yang sifatnya sosial, psikis, fisik, emosi dan lain sebagainya adalah pengertian dari konsep diri.

Menurut Burn dalam (Surna, 2014:60) kepercayaan seseorang pada pribadinya sendiri adalah pengertian dari konsep diri. Hakikat jati diri itu sebenarnya mengimplementasikan pribadi seseorang di dunia nyata, sikap ia menurut pikirannya sendiri serta menentukan akan menjadi apa ia di kemudian hari.

Berdasarkan penjelasan sebelumnya, konsep diri adalah penilaian seseorang akan kepribadiannya. Pemahaman seorang anak tentang konsep diri memberikan dampak pada pola pikir, cita-cita, perasaan dan tujuan hidup yang ingin ia capai (Anissa and Handayani, 2012:59).

Menurut Surna, (2014:62) ada beberapa cara yang bisa dilakukan dalam meningkatkan konsep diri akademik peserta didik antara lain:

a. Guru hendaknya dapat membangun suasana pembelajaran yang dapat

47 | Jurnal Ilmiah "Pendidikan Dasar" Vol. VII No. 1 Januari 2020 
meningkatkan semangat peserta didik dalam belajar sehingga ia dapat mengoptimalkan potensinya.

b. Guru hendaknya dapat berhubungan baik dengan siswanya, di dalam aktivitas belajar seorang guru harus dapat menempatkan dirinya diantara kehidupan pribadi peserta didik yang tengah berada pada tahap optimalisasi kemampuannya. Dengan demikian guru dapat memahami apa yang menjadi keinginan, kekurangan maupun kekuatan dari peserta didik yang membuat guru dapat membantunya dalam mengatasi masalah yang tengah dihadapi peserta didik.

c. Guru hendaknya dapat membangun suasana belajar yang menantang, ajarkan siswa agar dapat bersaing baik dengan dirinya sendiri maupun dengan temannya. Hal tersebut membuat ia belajar serta bekerja dengan optimal, belajar untuk mengerjakan tugas dengan baik, belajar dalam memahami kemampuan dirinya, belajar untuk tidak mudah dengan apa yang telah ia capai, serta belajar memahami kekuatan dirinya sendiri serta senantiasa menghargai apa yang telah dicapai.

Menurut Harjasuganda (2008:4), guru hendaknya mengerti komponen apa saja nantinya akan membangun serta mengoptimalkan konsep diri bagi peserta didik antara lain.

a. Perasaan dihargai di lingkungannya, seharusnya seorang guru bisa membuat suasana kelas nantinya membuat setiap siswa merasa diakui di lingkungannya sehingga dapat menumbuhkan sikap percaya dirinya ditengah masyarakat. Perasaan dihargai dan bernilai di lingkungan yang ia tempati adalah satu komponen dalam mengoptimalkan konsep diri yang baik bagi peserta didik.

b. Perasaan sanggup, seorang anak jika diberikan peluang dan pengetahuan yang baik dalam pembelajaran kecenderungan mereka menunjukkan konsep diri yang bagus. Hal demikian membuat dirinya merasa percaya diri akan tugas yang sedang dikerjakannya.

c. Perasaan patut, dalam pembelajaran penting kiranya diberikan umpan balik, salah satu fungsinya yaitu memberikan gambaran tentang kemampuan masing-masing anak.

d. Perasaan menerima keadaan diri sendiri, guru pada hakikatnya dijadikan sebagai tumpuan peserta didiknya dalam mendapatkan pujian, maka dari itu seharusnya guru memberikan pujian kepada

48 | Jurnal Ilmiah "Pendidikan Dasar” Vol. VII No. 1 Januari 2020 
mereka sehingga ia merasa senang akan dirinya.

e. Menerima kekurangan, seorang peseta didik yang mempunyai konsep diri yang bagus, sejatinya mereka mampu menyadari kekurangannya.

f. Keistimewaan, seorang guru seharusnya dapat menyadari bahwa masing-masing anak didik mempunyai kepribadian serta potensi yang istimewa. Masingmasing anak didik tidak sama satu dengan yang lainnya. Menghormati keistimewaan setiap anak didik berdampak kepada pembentukan konsep diri yang optimal pada diri anak didik itu sendiri.

Menurut Lutan dalam (Harjasuganda, 2008:4) hal-hal yang berpengaruh terhadap konsep diri yaitu menghormati diri kita sendiri dan penilaian terhadap diri kita yang sebenarnya. Keduanya akan sangat dipengaruhi oleh kompetensi guru dalam memberikan motivasi agar anak didik terbiasa menghargai keberhasilan yang ia capai, menyadari kelemahannya serta apa saja yang menjadi pemicunya. Menurut Pambudi (2012:150), perkembangan konsep diri disebabkan oleh berbagai faktor dimana faktor tersebut akan memunculkan tekanan bagi individu.

\section{SIMPULAN}

Setiap anak mempunyai ide kreatif tetapi yang penting untuk diperhatikan yaitu bagaimana mengoptimalkan ide kreatif dari setiap anak didik. Kreativitas itu bukanlah potensi dari sejak lahir, itu merupakan kemampuan yang dapat didalami serta dikembangkan. Kreativitas penting untuk dioptimalkan karena dalam kehidupan sehari-hari. Anak didik dihadapkan dengan berbagai persoalan, dengan kreativitas anak didik dapat memecahkan suatu permasalahan serta berpengaruh kepada prestasi akademiknya. Maka dari itu proses perkembangan kreativitas anak sangat penting untuk diperhatikan agar proses perkembangannya berjalan optimal.

Kreativitas dikembangkan sejak usia sekolah dasar karena merupakan dasar menuju tahap berikutnya. Begitu pun dengan pengembangan konsep diri, upaya yang dilakukan dalam mengoptimalkan konsep diri kepada anak didik merupakan tanggung jawab bersama antara guru, orang tua dan lingkungan di sekitarnya. Jika perkembangan kreativitas dan konsep diri pada anak SD berjalan optimal maka akan lahir generasi yang kreatif dengan aktualisasi diri yang bagus.

49 | Jurnal Ilmiah "Pendidikan Dasar” Vol. VII No. 1 Januari 2020 


\section{DAFTAR PUSTAKA}

Anissa, Nova, and Agustin Handayani. 2012. "Hubungan Antara Konsep Diri Dan Kematangan Emosi Dengan Penyesuaian Diri Istri Yang Tinggal Bersama Keluarga Suami." Jurnal Psikologi Pitutur 1(1): 57-67.

Bayanie, Mareta. 2012. "Hubungan Motivasi Berprestasi Dan Konsep Diri Dengan Sikap Kreatif." Jurnal Pendidikan Usia Dini 7(1): 155-72.

Budiarti, Yesi. 2015. "Pengembangan Kemampuan Kreativitas Dalam Pembelajaran.” PROMOSI (Jurnal Pendidikan Ekonomi) 3(1).

Harjasuganda, Djukanda. 2008. "Pengembangan Konsep Diri Yang Positif Pada Siswa SD Sebagai Dampak Penerapan Umpan Balik (Feedback) Dalam Proses Pembelajaran Penjas." Dalam Jurnal Pendidikan Dasar Nomor 9(8): 4-5.

Muawanah, Lis Binti. 2012. "Kematangan Emosi, Konsep Diri Dan Kenakalan Remaja." Jurnal Persona 1(1): 6-14.

Munandar, Haris. 2015. "Berorientasi Nilai Islami Pada Materi Hidrolisis." 03(01): 27-37.

Munandar, Utami. 2004. Pengembangan Kreativitas Anak Berbakat. Jakarta: PT.Asdi Mahasatya.

Pambudi, Prabawati Setyo. 2012. "Hubungan Konsep Diri Dengan Prestasi Akademik Pada Mahasiswa Keperawatan." JURNAL NURSING STUDIES 1(1): $149-56$.
Suherman, Ayi. 2010. "Model Pembelajaran Pakem Dalam Pendidikan Jasmani Di Sekolah Dasar.” Jurnal Penelitian Pendidikan 11(1): 131-41.

Surna, I Nyoman. 2014. Psikologi Pendidikan. Jakarta: Erlangga.

Zed, Mestika. 2003. Metode Penelitian Kepustakaan. Jakarta: Yayasan Obor Indonesia. 